\title{
The EU law and the law of third countries: problems of interaction
}

\author{
Dmitriy Viacheslavovich Galushko*, Natalya Valerievna Oganova, Andrey Leonidovich \\ Belousov, Elena Valerievna Grigorovich, and Aleksey Valerievich Sereda
}

Financial University under the Government of the Russian Federation, Faculty of Law, Department of Legal Regulation of Economic Activity, Moscow, Russia

\begin{abstract}
The article discusses the problems of the interaction process of legal systems of international integration organizations with law of states that are not members of those entities. The research has been conducted on the example of the European Union. The authors conclude that the degree of influence of the international treaties between the EU and third countries on the legal orders of these states differs depending on the level of cooperation between the parties, which is precisely determined by such agreements. The European Union law is the main means of spreading the influence of the European Union on the legal systems of non-member states. Approximation of national legislation with the European Union's acquis is a consistent process of approximation of the legal system of the state, including legislation, lawmaking, legal technique, law enforcement practice in accordance with the criteria set by the Union. Peculiarities of the legal approximation of law of particular states with law of the European Union are determined by the nature of the relationship between those subjects, by the goals set for such cooperation and fixed in mutual international treaties, as well as by the peculiarities of the state mechanism and the legal system of the respective state. Consequently, regarding European Union - Russia interaction in the field, regulatory engagement can be hardly called as efficient, smooth, and cloudless.
\end{abstract}

Keywords: regional integration, international integration organization, the European Union, approximation

\section{Introduction}

At present, the extension of the European Union's (EU) legal norms beyond its borders is one of the most important directions of its foreign policy [1]. This concerns, first, relations with those states that are not part of it, but the stabilization of relations with which serves the foreign policy interests of the expanding Union [2]. In addition, researchers draw attention to the fact that a relatively new phenomenon for the EU characteristic is the adoption by its institutions of acts addressed to legal entities of third countries (the socalled extraterritorial action) [3]. This practice raises a lot of controversy from the point of view of the concept of state sovereignty, since it aims to impose on other subjects of

\footnotetext{
*Corresponding author: galushkodv@gmail.com
} 
international law such a regime of cooperation that, under certain circumstances, may deprive them of the means of effectively protecting their interests.

International treaties concluded with them serve as the legal basis for the interaction of EU law with legal orders of third countries that are not part of the Union. Moreover, when concluding international agreements with third countries, the EU widely uses the practice of including into these agreements provisions similar to those contained in the constituent agreements or acts of EU institutions that are addressed to the member states, as well as provisions that prescribe third countries to adapt their legislation to the relevant legal acts of the European Union, thereby bringing it closer to the provisions of the aquis communautaire. This creates a legal basis for the assimilation of the provisions established by the law of the European Union, the internal legal order of third countries [4].

\section{Materials and methods}

The methodological basis of the paper is a set of methods of scientific knowledge, which are inherent in legal science in general and International and integration law in particular. General philosophical approaches, general scientific and special legal research methods are used to solve the scientific problem. These methods and approaches provided a comprehensive and comprehensive study of the issue raised in the paper and the reliability of the results obtained by the authors.

\section{Results}

In general, the degree of influence of the provisions of international treaties between the EU and third countries on the legal orders of these states differs depending on the level of cooperation between the parties, which is precisely determined by such agreements. With the entry into force of the Lisbon Treaty, the EU's spheres of competence were expanded again [5]. Therefore, this is reflected in the international treaties of the organization. From now on, the parties have introduced norms relating to new areas of cooperation to the EU international agreements, which created the preconditions for extending the convergence of the legislation of the associated countries with the EU law to new elements of the acquis communautaire. The existence of various types of the EU treaties with third countries contributes to a different degree of interaction of EU law with law of third countries, thereby determining the intensity of the relationship between the parties. This process is most intensively carried out within the framework of the association provided for by the Agreement on the Establishment of the European Economic Area (hereinafter referred to as the EEA) [6], which actually reproduces the main provisions of the Treaty on the EU and acts of the EU institutions, providing for the fullest recognition by them of the EU law in the relevant areas. The emphasis here is on the inclusion of entire blocks of EU law to national law of the EEA member states, both by reproducing the provisions of the EU primary law in the Agreement on the EEA Establishment, and by referring to the EU regulations and directives, which are referenced in the annexes to the Agreement and acts of the bodies of the association, and the provisions of which become part of the national legal order of the associated states.

\section{Discussion}

Due to the extension to all important areas of cooperation defined by the Agreement on the EEA Establishment, as well as the use of a wide range of methods of its implementation, the interaction and approximation of the legislation of the associated EEA member states 
with the EU law ensure a very high level of integration of their economies. Having agreed on the priority of the EU institutions within the framework of the Single Internal Market and the Schengen rules, Norway, Iceland and Liechtenstein are obliged to incorporate the legislation adopted in the EU, thus changing their economic, economic and partly political structure [7].

When implementing interaction, all associated states must deal with the same EU acts. In practice, there is a selective approach, when for individual associated countries or groups of such countries, depending on the goals and areas of cooperation defined by the agreement, from the whole mass of the EU acts, those are specially selected, the implementation of which should ensure that the parties fulfill their obligations. The goals and areas of cooperation themselves, as a rule, take into account the special nature of relations with a particular country, although some areas (for example, antimonopoly legislation, etc.) are enshrined in all association agreements without exception [8].

Thus, for the associated countries of the Central and Eastern Europe, in order to determine specific commitments to join the European Union, in May 1995 the EU Commission adopted a special White Paper [9]. Particular attention in this document was paid to the adaptation of the national legislation of the associated countries to the law of the European Union, the extension of the organization's law to these countries was also considered. The White Paper is a guide for use by current and future associated countries. Its provisions are not binding, but serve as a guide on the path to the EU accession.

Approximation, or rather, adaptation of law of associated countries to the EU law is more limited than the one that is carried out within the EEA, since it concerns a much smaller number of the EU acts, covering only the areas of cooperation clearly defined by agreements. The adaptation methods are reduced mainly to the accession of the associated countries to the relevant multilateral international treaties, which have already been implemented in the EU law.

To date, the EU has entered into partnership and cooperation agreements with most of the countries that were part of the former USSR, among which there are both neighboring states and the EU partner states, including the Russian Federation [10]. In general, the normative sphere occupies the most important place in the relations of the European Union with Russia, however, as well as with other states, and was included in the Agreement on Partnership and Cooperation between the European Communities and the Russian Federation [11]. In general, relations between the European Union and the Russian Federation are a serious test for the "normative power of Europe". This concept, formulated by J. Manners, indicates that the European Union is, first, values and norms such as peace, freedom, democracy, the rule of law and respect for human rights, as well as a number of minor ones - social solidarity, non-discrimination, sustainable development and good governance [12]. Given the scale and ambitions of both parties, regulatory engagement can be hardly called as efficient, smooth, and cloudless.

The PCA 1994 is of a basic nature, it contains general provisions on cooperation between the European Union and Russia, since many of its provisions need to be further developed and concretized within the framework of special bilateral agreements on certain issues. Some articles of the PCA 1994 stipulate not only the possibility, but even the necessity of concluding such agreements (for example, Articles 21-22) [13].

Subsequent EU-Russia documents on cooperation confirmed the goal of legal approximation of the legal systems of both parties [14]. The EU general strategy towards Russia in 1999 clarified, that "the progressive convergence of legislation and standards between Russia and the European Union, in accordance with the Partnership and Cooperation Agreement, will contribute to the creation of a common economic space" [15].

Approximation processes are a manifestation of the dynamic, evolutionary dimension of law, a way of implementing its modernizing function, which was actualized at a new round 
of social progress with renewed vigor. In practice, approximation characterizes the process of bringing the legislation of third countries in line with the norms of the EU law, however, it takes place outside the Union and concerns third countries, and its main goal is the same legal conditions for the subjects of cooperation of the parties.

In general, as noted by Yu.A. Tikhomirov, the process of approximation of national legal systems provides for:

- development of a general policy of the state legal development;

- implementation of measures to overcome legal differences;

- taking steps to develop joint legal rules [16].

It can be argued that the goal of approximation of the legislation will be achievable to the extent that its mechanism is effective in the corresponding state (the latter includes the institutional and regulatory part). It is noted that Russia has undergone a number of reforms in those areas in which the experience of the EU regulation was chosen due to its effectiveness, in particular, to ensure compliance with the WTO regime [17].

The content of the EU agreements on partnership and cooperation with third countries allows us to state that they relate to a fairly wide range of areas of legal regulation and are not limited to issues of customs procedures and trade in goods. They penetrate deeply into the domestic politics and legislation of these countries, require their governments to make significant efforts to adapt legislation both in the political and economic spheres, and in other issues of the life of the society [18]. At the same time, third countries, given the principled character of some of their national interests, may express certain protective clauses about the impossibility of perceiving some provisions of the EU legal order. That is, the specific content of the acquis communautaire may differ depending on the approaches of the parties to determining the level and purpose of their cooperation [19].

\section{Conclusion}

In conclusion, it can be noted that EU law acts as a means of spreading the EU influence on the legal systems of countries that are not members of this international integration organization, and protecting its interests, the interests of the member states and their individuals and legal entities.

In general, the approximation of national legislation with the EU's acquis is a consistent process of approximation of the legal system of the state, including legislation, lawmaking, legal technique, law enforcement practice in accordance with the criteria set by the Union. Therefore, the process of approximation of the legislation must be approached more broadly, since it includes a species diversity of processes of changing the system of law, the key component of which is active and systematic impact on the national system of law and its segments in order to ensure an appropriate degree of functional and (or) structural similarity of the national legal order with the chosen political way of a model analogue and thus providing controllability of the process of development of society in a predictable direction.

The conducted analysis shows that the peculiarities of the legal approximation of law of particular states with law of the European Union are determined by the nature of the relationship between those subjects, by the goals set for such cooperation and fixed in mutual international treaties, as well as by the peculiarities of the state mechanism and the legal system of the respective state.

\section{References}


1. P.J. Cardwell, EU External Relations Law and Policy in the Post-Lisbon Era. (Springer, The Hague, 2012)

2. S. Lavenex, J. Europ. Publ. Pol. 11(4), 680-700 (2004). https://doi.org/10.1080/1350176042000248098

3. J. Scott, Com. Market Law Rev. 51(5), 1343-1380 (2014)

4. Ch. Hillion, The evolving system of the EU external relations as evidenced in the EU partnerships with Russia and Ukraine, Doctoral Thesis (Leiden University, 2005)

5. S.Ju. Kashkin, A.O. Chetverikov (eds.), Evropeiskii soyuz: Osnovopolagayushchie akty v redaktsii Lissabonskogo dogovora s kommentariyami [The European Union: Fundamental acts as amended by the Lisbon Treaty with comments] (INFRA-M, Moscow, 2017)

6. Agreement on the European Economic Area (EEA) (1994, 2016). Accessed on: July 05, 2021. [Online]. Available: http://www.efta.int/media/documents/legaltexts/eea/the-eeaagreement/Main\%20Text\%20of\%20the\%20Agreement/EEAagreement.pdf

7. A.A. Gromyko, V.P. Fedorova (eds.), Evropa XXI veka. Novye vyzovy i riski [Europe in the 19th Century. New Challenges and Risks] (Nestor-History, Moscow, 2017)

8. N. Ghazaryan, The European Neighbourhood Policy and the Democratic Values of the EU: A Legal Analysis (Hart Publishing, Oxford, 2014)

9. White Paper on the Preparation of the Associated Countries of Central and Eastern Europe for Integration into the Internal Market of the Union (1995). Accessed on: July 05, 2021. [Online]. Available:

http://www.cvce.eu/en/obj/white_paper_on_the_preparation_of_the_associated_countr ies_of_central_and_eastern_europe_for_integration_into_the internal_market_of_the union_com_9 $\overline{5} \_16 \overline{3}-\mathrm{en}-\mathrm{f32} \overline{0} 7 \mathrm{cf5}-\mathrm{df} 8 \mathrm{~b}-\overline{4} 75 \mathrm{a}-\mathrm{bd} 06-\overline{6 \mathrm{fc}} 7 \mathrm{~d} \overline{8} 0 \mathrm{~b} 0 \overline{\mathrm{c}} 9 \mathrm{e} \cdot \mathrm{html}$

10. D.V. Galushko, Vzaimodeistvie prava Evropeiskogo Soyuza s pravom gosudarstvchlenov i tretikh stran [Relationships between EU law and law of member-states and third countries] (Publishing House of VSU, Voronezh, 2018)

11. Soglashenie o partnerstve i sotrudnichestve, uchrezhdayushchee partnerstvo mezhdu Rossiiskoi Federatsiei, s odnoi storony, i Evropeiskimi soobshchestvami i ikh gosudarstvami-chlenami, s drugoi storony [Agreement on partnership and cooperation establishing a partnership between the European Communities and their Member States, of one part, and the Russian Federation, of the other part]. Accessed on: July 05, 2021. [Online]. Available:

http://www.consultant.ru/document/cons_doc_LAW_121271/

12. I. Manners, J. Com. Market Stud. 40(2), 235-258 (2002)

13. S.Ju. Kashkin, Trends in Rus.-Europ. Rel. 6, 41-76 (2005)

14. V.A. Ryzhkov, Modern Eur. 3, 13-24 (2019). http://dx.doi.org/10.15211/soveurope320191324

15. Common Strategy of the European Union of 4 June 1999 on Russia (1999/414/CFSP). Accessed on: July 05, 2021. [Online]. Available: https://www.cvce.eu/content/publication/1999/1/1/6b5bdd85-e486-4cd8-aaaa9dad24c7a50a/publishable_en.pdf

16. Ju.A. Tikhomirov, Kurs sravnitelnogo pravovedeniya [Course of comparative law] (NORMA, Moscow, 1996)

17. A. Matta, Obnovlenie protsessa pravovoi approksimatsii ES-Rossiya: problemy i dilemmy. Otnoshenii Rossii-ES na poroge peremen [Updating the EU-Russia Legal 
Approximation Process: Problems and Dilemmas. Russia-EU relations on the threshold of change] (Axiom Publishing House, Moscow, 2009)

18. M.L. Entin, E.G. Entina, V poiskakh partnerskikh otnoshenii VIII: Rossiya i Evropeiskii soyuz v 2018 - pervoi polovine 2019 g. [In Search of Partnership VIII: Russia and the European Union in 2018 - first half of 2019] (Zebra E, Galaktika, Moscow, 2019)

19. P.N. Birjukov, D.V. Galushko, Sravnitelnoe pravovedenie [Comparative Jurisprudence] (Prospect, Moscow, 2020) 